Tạp chí Khoa học và Công nghệ biển T11 (2011). Số 3. Tr 85 - 96

\title{
TRŨ̉ LƯợNG TỨC THỜI VÀ PHÂN BỐ NGUỒN LỢI CÁ CHỈ VÀNG (SELAROIDES LEPTOLEPIS) Ở VÙNG BIỂN PHÍA NAM VIẸTT NAM DỰA TRÊN KẾT QUẢ ĐIỀU TRA BẰNG PHƯƠNG PHÁP THỦY ÂM
}

\author{
VŨ VIẸT HÀ
}

Viện Nghiên cứu Hải sản

\begin{abstract}
Tóm tắt: Số liệu điều tra bằng phương pháp thuỷ âm kết hợp đánh luới kiểm tra tín hiệu đàn cá năm 2005 được sủ dụng để đánh giá trũ luợng nguồn lợi cá chỉ vàng ở vùng biển phía Nam Việt Nam. Trũ luợng nguồn lợi tức thời uớc tính khoảng 177-351 ngàn tấn. Cấu trúc quần thể cá chỉ vàng ở mùa gió Tây Nam thuộc nhóm duoói $10 \mathrm{~cm}$ và ở mùa gió Đông Bắc chủ yếu thuộc nhóm trên $10 \mathrm{~cm}$ cho thấy luợng bổ sung nguồn lọi của loài chủ yếu diễn ra trong mùa mùa gió Tây Nam. Khu vưc phân bố tập trung của cá chỉ vàng trong mùa gió Đông Bắc chủ yếu giới hạn tù $9^{\circ} 00 N$ xuống phía Nam. Ở mùa gió Tây Nam khu vưc phân bố tập trung nằm rải rác, trong đó các vùng biển phía Đông Nam đảo Phú Quý, ngoài khơi đảo Côn Sơn và khu vưc phía Nam mũi Cà Mau là nơi có mật độ phân bố cao hơn.
\end{abstract}

Tù khoá: thủy âm, cá chỉ vàng, trũ luợng, độ phong phú nguồn lọi

\section{MỞ ĐẦU}

Cá chỉ vàng (Selaroides leptolepis) [11] thuộc họ cá khế (Carangidae), phân bố chủ yếu ở các vùng biển nhiệt đới phía Tây Thái Bình Dương, giới hạn phía Bắc là Nhật Bản và phía Nam là Australia. Cá chỉ vàng có tập tính hợp đàn, thường phân bố nhiều ở những khu vực có nền đáy mềm và khu vực ven bờ, cửa sông. Kích thước tối đa của cá chỉ vàng khoảng $22 \mathrm{~cm}$, trong sản lượng khai thác chiếm ưu thế là nhóm cá có kích thước trên dưới $15 \mathrm{~cm}$. Thức ăn chủ yếu của cá chỉ vàng là các loài động vật phù du [9].

Kết quả điều tra nguồn lợi ở biển Việt Nam cho thấy, cá chỉ vàng phân bố chủ yếu ở vùng biển ven bờ, tập trung ở dải độ sâu dưới 30 m nước. Vùng biển Đông Nam bộ là khu vực có nguồn lợi cá chỉ vàng phong phú hơn so với các vùng biển khác $[1,3,4]$. Năng suất khai thác cá chỉ vàng bằng lưới kéo đáy khoảng 2-3 kg/giờ ở vùng biển Đông Nam bộ [4] và dưới $1 \mathrm{~kg} /$ giờ ở vùng biển vịnh Bắc bộ [3]. Kích thước cá khai thác chủ yếu trong khoảng 11-14 cm. Nguồn lợi cá chỉ vàng ở biển Việt Nam nói chung đang trong chiều hướng suy giảm $[1,3,4]$. 
Nguồn lợi cá biển nước ta chủ yếu được điều tra, đánh giá bằng tàu đánh lưới kéo đáy. Đối với các loài cá có tập tính tụ đàn và không phân bố sát đáy như cá chỉ vàng thì việc áp dụng phương pháp điều tra bằng tàu đánh lưới kéo đáy sẽ tồn tại sai số hệ thống do lưới kéo đáy không thể thu được mẫu khi cá phân bố chủ yếu ở tầng trên. Đối với phương pháp thuỷ âm các hạn chế nói trên sẽ được giảm thiểu vì vậy độ chính xác của kết quả nghiên cứu cũng sẽ tăng lên [6].

Với bộ số liệu thủy âm kết hợp đánh lưới kéo thu thập được trong các tháng 4,5 và 11, 12 năm 2005 ở vùng biển phía Nam Việt Nam của đề tài "Nghiên cứu trữ lượng và khả năng khai thác cá nổi nhỏ chủ yếu là các loài cá nục, cá trích, cá bạc má ở biển Việt Nam" ${ }^{[2]}$, bài viết này sẽ phân tích, đánh giá và cung cấp những thông tin cơ bản về trữ lượng nguồn lợi và khu vực phân bố của các loài cá cá chỉ vàng ở vùng biển Đông và Tây Nam bộ, Việt Nam.

\section{TÀI LIỆU VÀ PHƯƠNG PHÁP NGHIÊN CÚU}

\section{Nguyên lý chung của phương pháp thủy âm áp dụng trong đánh giá trữ lượng nguồn lợi cá biển}

Máy dò thủy âm sử dụng trong điều tra, đánh giá nguồn lợi cá biển hoạt động trên nguyên tắc phát và thu lại tín hiệu ở dạng số hóa [10], dữ liệu đầu ra được hiệu chỉnh bằng cách chuẩn hóa theo quả cầu tiêu chuẩn [8]. Tiết diện âm phản hồi của quả cầu hiệu chỉnh được quy chuẩn theo một hải lý vuông và được mô tả theo công thức

$$
S_{A}=\frac{\sigma .1852^{2}}{\Psi \mathrm{Z}^{2}}
$$

Trong đó, $\sigma$ là tiết diện âm phản hồi của tín hiệu, Z là độ sâu trung bình của tín hiệu (m) và $\psi$ là góc quét lý thuyết của chùm sóng âm. Trong đánh giá trữ lượng cá biển, mật độ phân bố của cá trên một đơn vị diện tích $\left(\rho_{\mathrm{A}}\right)$ được mô tả theo công thức [5]:

$$
\rho_{A}=\frac{s_{A}}{\sigma}
$$

Tiết diện âm phản hồi của cá được tính từ hệ số phản hồi âm (Target Strength, TS), đó là đại lượng được sử dụng để chuyển đổi năng lượng âm phản hồi sang thành mật độ của cá trong khối nước, và được biểu diễn theo công thức:

$$
T S=10 . \log (\sigma / 4 \pi)
$$


và

$$
\sigma=4 \pi \cdot 10^{\frac{T S}{10}}
$$

Số lượng cá thể trong vùng biển nghiên cứu (A, hải lý vuông) được ước tính theo công thức [5]

$$
N=\rho_{A} \cdot A=\frac{s_{A}}{4 \pi \cdot 10^{T S / 10}} \cdot A
$$

\section{Tài liệu nghiên cứu}

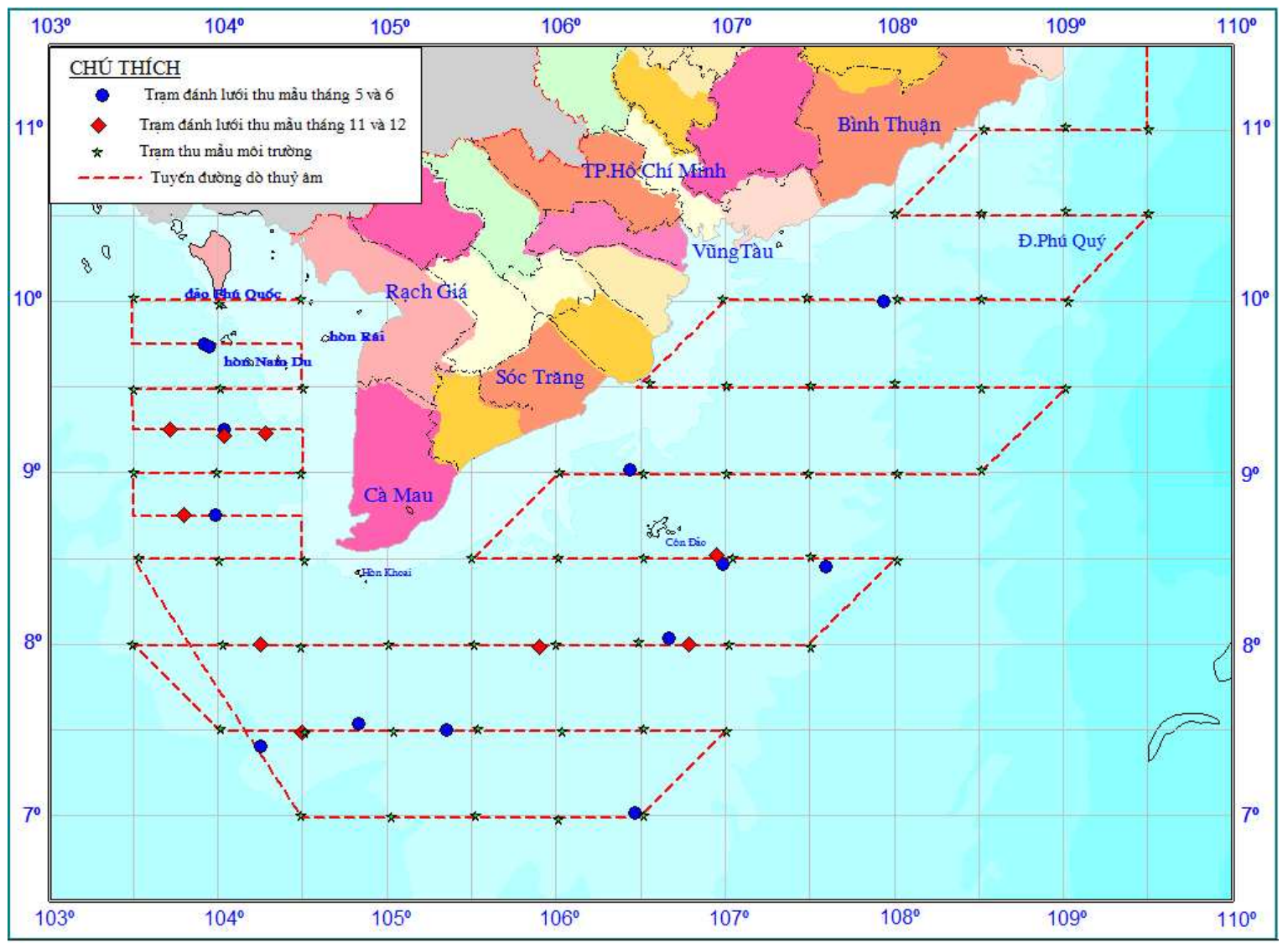

Hình 1: Tuyến đường dò thủy âm và vị trí các trạm đánh lưới của các chuyến điều tra nguồn lợi cá nổi nhỏ ở vùng biển Đông Nam bộ năm 2005

Số liệu được thu thập bằng phương pháp thủy âm kết hợp với đánh lưới kéo từ ngày 30/4 đến 18 tháng 5 và từ ngày 26/11 đến 10/12 năm 2005 ở vùng biển Đông - Tây Nam bộ do đề tài "Nghiên cứu trữ lượng và khả năng khai thác cá nổi nhỏ chủ yếu là các loài cá 
nục, cá trích, cá bạc má ở biển Việt Nam" thực hiện. Tổng chiều dài tuyến đường dò là 2.565 hải lý, với 9 mặt cắt giới hạn từ $7^{\circ} 00 \mathrm{~N}$ đến $11^{\circ} 00 \mathrm{~N}$. Khoảng cách giữa các mặt cắt ở vùng biển Đông Nam bộ là 30 hải lý và vùng biển Tây Nam bộ là 15 hải lý (Hình 1).

\section{Phương pháp nghiên cứu}

\subsection{Phương pháp thu thập số liệu}

Bảng 1: Các thông số cài đặt thiết bị thủy âm trong chuyến điều tra nguồn lợi cá nổi nhỏ ở vùng biển phía Nam Việt Nam, tháng 5-6 và tháng 11-12 năm 2005

\begin{tabular}{|c|c|c|c|}
\hline \multicolumn{2}{|c|}{ Thông số } & \multirow{3}{*}{ 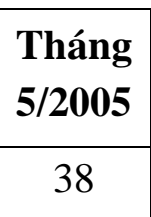 } & \multirow{3}{*}{$\begin{array}{c}\text { Tháng } \\
\text { 11/2005 }\end{array}$} \\
\hline Tiếng Việt & Tiếng Anh & & \\
\hline Tần số & Frequency $(\mathrm{kHz})$ & & \\
\hline Hệ số hấp thụ & Absoption coefficent $(\mathrm{dB} / \mathrm{km})$ & 5,68 & 5,43 \\
\hline Khoảng xung & Pulse duration (ms) & 1,0 & 1,0 \\
\hline Công suất & Power (w) & 1000 & 1000 \\
\hline Hệ số phản hồi âm chuyển đổi & TS transducer gain $(\mathrm{dB})$ & 21,71 & 20,67 \\
\hline $\begin{array}{c}\text { Hệ số hiệu chỉnh diện tích âm } \\
\text { phản hồi }\end{array}$ & $\mathrm{s}_{\mathrm{A}}$ Correction $(\mathrm{dB})$ & $-0,58$ & $-0,49$ \\
\hline Góc phát - thu tín hiệu & Two-way beam angle (dB) & $-15,5$ & $-15,5$ \\
\hline $\begin{array}{l}\text { Độ nhạy của đầu dò theo chiều } \\
\text { dọc }\end{array}$ & Angle sensivity alongships $\left({ }^{\circ}\right)$ & $-12,5$ & $-12,5$ \\
\hline $\begin{array}{c}\text { Độ nhạy của đầu dò theo chiều } \\
\text { ngang }\end{array}$ & Angle sensivity athwartships $\left({ }^{\circ}\right)$ & $-12,5$ & $-12,5$ \\
\hline $\begin{array}{c}\text { Góc nhận tín hiệu chuẩn theo } \\
\text { chiều dọc }\end{array}$ & Angle offset alongships $\left({ }^{\circ}\right)$ & 0,28 & 0,28 \\
\hline $\begin{array}{c}\text { Góc nhận tín hiệu chuẩn theo } \\
\text { chiều ngang }\end{array}$ & Angle Offset athwartships $\left({ }^{\circ}\right)$ & $-0,05$ & $-0,05$ \\
\hline Độ rộng góc quét theo chiều dọc & $3 \mathrm{~dB}$ Beamwidth alongships $\left({ }^{\circ}\right)$ & 12,02 & 12,35 \\
\hline $\begin{array}{c}\text { Độ rộng góc quét theo chiều } \\
\text { ngang }\end{array}$ & 3dB Beamwidth athwartships $\left({ }^{\circ}\right)$ & 11,98 & 12,26 \\
\hline Băng thông & Bandwidth $(\mathrm{kHz})$ & 2,43 & 2,43 \\
\hline
\end{tabular}


Số liệu thủy âm được thu thập bằng tàu nghiên cứu Biển Đông lắp đặt hệ thống máy dò SIMRAD EK60, tần số $38 \mathrm{kHz}$. Đầu dò thủy âm được gắn trực tiếp vào đáy tàu nghiên cứu và được nối bộ phận chuyển đổi và khuyếch đại (GPT) tín hiệu trước khi kết nối với máy tính bằng hệ thống mạng nội bộ (Local Area Network, LAN). Trước khi tiến hành thu thập tín hiệu thủy âm, hệ thống máy dò được chuẩn hóa theo hướng dẫn của Foote et al. [8]. Các thông số cài đặt thiết bị thủy âm trong các chuyến điều tra được trình bày ở Bảng 1 .

Tín hiệu thủy âm thu thập được lưu lại dưới định dạng EK60, bao gồm toàn bộ các thông tin thu thập được trên đường dò (vị trí, độ sâu, thời gian, tín hiệu bắt gặp, tốc độ hành trình...) . Trên các đường dò thủy âm, tốc độ hành trình của tàu nghiên cứu dao động trong khoảng 8-10 hải lý/giờ.

Các trạm thu mẫu bằng lưới kéo đáy hoặc trung tầng trên các tuyến đường dò được thực hiện bắt gặp tín hiệu đàn cá. Lưới kéo đáy sử dụng để thu mẫu có kích thước mắt lưới ở đụt $2 \mathrm{a}=22 \mathrm{~mm}$. Các mẻ lưới được thực hiện vào ban ngày. Thời gian kéo lưới trung bình khoảng 1 giờ, tốc độ kéo lưới dao động trong khoảng 3-4 hải lý/giờ.

Cá chỉ vàng thu được trong mẻ lưới được phân tích sinh học, gồm đo chiều dài tiêu chuẩn, chiều dài đến chẽ vây đuôi và chiều dài toàn thân (đơn vị là $\mathrm{cm}$ ), cân khối lượng (đơn vị là gam), xác định độ chín muồi tuyến sinh dục và độ no dạ dày.

\subsection{Phương pháp phân tích số liệu}

Trữ lượng nguồn lợi của loài cá được ước tính cho từng ô biển $1^{\circ}$ kinh tuyến $\mathrm{x} 1^{\circ}$ vĩ tuyến dựa trên số liệu tích phân âm thu được trên các đường dò ${ }^{[5]}$. Trữ lượng nguồn lợi của loài trong vùng biển nghiên cứu là tổng trữ lượng ước tính được từ các ô biển và được tính theo công thức (5). Tiết diện âm phản hồi của cá chỉ vàng được ước tính theo phương trình $\mathrm{TS}=20 \log (\mathrm{L})-68 \mathrm{~dB}$, đây là phương trình tương quan giữa chiều dài và hệ số phản hồi âm được xác định bằng sự kết hợp nhiều phương pháp thí nghiệm đo hệ số phản hồi âm khác nhau như phương pháp in situ, phương pháp ex situ và phương pháp mô hình hóa cấu trúc bóng bơi ${ }^{[7]}$ và được sử dụng chung cho các loài cá có bong bơi. Khi đã ước tính được số lượng cá thể của loài trong ô biển thì phương trình tương quan chiều dài khối lượng của loài $\left(\mathrm{W}=\mathrm{a} \mathrm{L}^{\mathrm{b}} ; \mathrm{W}\right.$ là khối lượng cá thể tính bằng $\mathrm{kg}$ và $\mathrm{L}$ là chiều dài thân của cá thể, tính bằng $\mathrm{cm}$ ) được sử dụng để chuyển đổi số lượng cá thể sang khối lượng cá thể.

Bản đồ phân bố của cá bạc má, cá chỉ vàng và cá ngân ở vùng biển phía Nam Việt Nam được thiết lập dựa trên nguồn số liệu thu thập được trên các đường dò thủy âm. Giá trị diện tích âm phản hồi $\left(\mathrm{m}^{2} / \mathrm{nm}^{2}\right)$ trên các đường dò với khoảng cách 5 hải lý/1 giá trị được sử dụng để phân tích phân bố không gian của loài. Phần mềm MapInfo phiên bản 7.0 tích hợp công cụ Vertical Mapper được sử dụng để biểu diễn phân bố của cá trên bản đồ. 


\section{KÊT QUẢ NGHIÊN CÚU VÀ THẢO LUẬN}

\section{Một số đặc điểm sinh học của cá chỉ vàng ở vùng biển phía Nam Việt Nam}

Trong năm 2005, cá chỉ vàng ở vùng biển phía Nam Việt Nam có kích thước dao động chủ yếu trong khoảng $2-17 \mathrm{~cm}$ ở mùa gió Tây Nam và $7-14 \mathrm{~cm}$ ở mùa gió Đông Bắc. Kết quả phân tích sinh học 533 cá thể cá chỉ vàng cho thấy, chiều dài trung bình của cá khoảng $11,4 \mathrm{~cm}$ (Bảng 2). Quần thể cá chỉ vàng trong mùa gió Tây Nam bao gồm cả các nhóm cá còn non, mới được bổ sung vào quần thể và các nhóm cá kích thước lớn. Ngược lại, ở mùa gió Đông Bắc, lượng cá nhỏ ít hơn, chiếm ưu thế trong quần thể là nhóm cá có kích thước $9-13 \mathrm{~cm}$.

Bảng 2: Kích thước trung bình $(\mathrm{cm})$ và số mẫu phân tích sinh học cá chỉ vàng ở vùng biển phía Nam Việt Nam năm 2005

\begin{tabular}{|c|c|c|c|c|}
\hline \multirow{2}{*}{ Mùa gió } & \multirow{2}{*}{ Số cá thể } & \multicolumn{3}{|c|}{ Chiều dài (cm) } \\
\cline { 3 - 5 } & & Nhỏ nhất & Trung bình & Lớn nhất \\
\hline Tây Nam & 371 & 2 & 11,5 & 17 \\
\hline Đông Bắc & 162 & 7 & 11,3 & 14 \\
\hline Tổng & 533 & 2 & 11,4 & 17 \\
\hline
\end{tabular}

Tương quan chiều dài khối lượng của cá cá chỉ vàng được mô tả ở Hình 2. Hệ số dị hóa $\mathrm{a}=0,00005$ và hệ số đồng hóa $\mathrm{b}=2,583$ đối với cá chỉ vàng cho thấy các loài này đều thuộc nhóm dị sinh trưởng. Cá chỉ vàng sinh trưởng chiều dài nhanh hơn so với sinh trưởng khối lượng.

\section{Trữ lượng nguồn lọii}

Trữ lượng và độ phong phú nguồn lợi cá cá chỉ vàng được trình bày ở bảng 3 , ước tính dao động trong khoảng 177 - 351 ngàn tấn.

Trữ lượng và độ phong phú nguồn lợi cá chỉ vàng có sự biến động rất lớn giữa hai mùa gió. Kết quả điều tra, đánh giá nguồn lợi cho thấy, ở mùa gió Tây Nam, trữ lượng nguồn lợi cá chỉ vàng ước tính khoảng 351 ngàn tấn tương ứng với $1.855 .828 \times 10^{6}$ cá thể. Trong đó nhóm cá có kích thước nhỏ, dưới $10 \mathrm{~cm}$ chiếm $13 \%$ về trữ lượng và $50,9 \%$ về số lượng cá thể. Nhóm cá có kích thước $10-15 \mathrm{~cm}$ chiếm tới $79,9 \%$ về trữ lượng nhưng chỉ chiếm $46,9 \%$ về số lượng cá thể. Cá có kích thước trên $15 \mathrm{~cm}$ chiếm tỉ lệ rất thấp trong 
quần thể cá chỉ vàng ở vùng biển Đông - Tây Nam bộ, với tỉ lệ tương ứng là $7 \%$ về trữ lượng và 2,2\% về độ phong phú (Bảng 3 ).

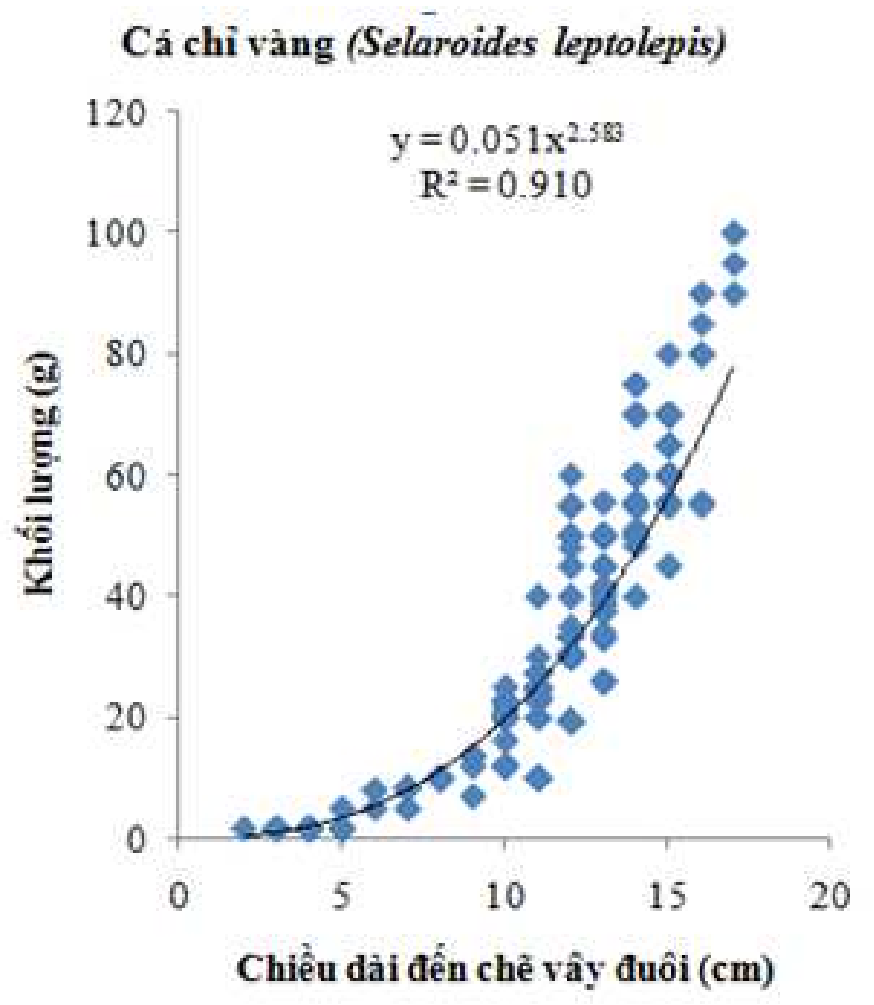

Hình 2: Tương quan chiều dài - khối lượng của cá cá chỉ vàng ở vùng biển Đông - Tây Nam bộ

Trong mùa gió Đông Bắc, kết quả điều tra cho thấy, trữ lượng nguồn lợi cá chỉ vàng ước tính khoảng 177 ngàn tấn, giảm 49,5\% so với trữ lượng ước tính trong mùa gió Tây Nam. Cấu trúc quần thể ở mùa gió Đông Bắc cũng có sự khác biệt lớn so với ở mùa gió Tây Nam, thể hiện ở tỉ lệ trữ lượng và độ phong phú nguồn lợi ở từng nhóm chiều dài. Nhóm cá có kích thước dưới $10 \mathrm{~cm}$ chiếm $15,9 \%$ về trữ lượng tương ứng với 32,4\% về độ phong phú. Quần thể cá chỉ vàng chủ yếu là nhóm cá có kích thước $10-15 \mathrm{~cm}$. Nhóm này chiếm tới $83,2 \%$ về trữ lượng và 67,3\% về độ phong phú. Nhóm cá lớn, kích thước trên 15 $\mathrm{cm}$ chiếm dưới $1 \%$ cả về trữ lượng và độ phong phú.

Đồ thị phân bố nguồn lợi và độ phong phú của cá chỉ vàng được trình bày ở Hình 3. Ở mùa gió Tây Nam, quần thể cá chỉ vàng gồm 4 nhóm chính thể hiện ở 4 đỉnh của đồ thị 
biểu diễn độ phong phú của loài. Trong mùa gió Đông Bắc, quần thể chủ yếu gồm 2 nhóm kích thước ưu thế là $6-8 \mathrm{~cm}$ và $11-13 \mathrm{~cm}$.

Bảng 3: Trữ lượng và độ phong phú nguồn lợi cá chỉ vàng ở vùng biển phía Nam Việt Nam

\begin{tabular}{|c|c|c|c|c|c|c|c|c|}
\hline \multirow{2}{*}{$\begin{array}{c}\text { Nhóm } \\
\text { chiều dài } \\
(\mathbf{c m})\end{array}$} & \multicolumn{4}{|c|}{ Mùa gió Tây Nam } & \multicolumn{3}{c|}{ Mùa gió Đông Bắc } \\
\cline { 2 - 9 } & Trữ lượng & \multicolumn{2}{|c|}{ Độ phong phú } & \multicolumn{2}{c|}{ Trữ lượng } & \multicolumn{2}{|c|}{ Độ phong phú } \\
\cline { 2 - 9 } & tấn & $\begin{array}{c}\text { Tỉ lệ } \\
(\%)\end{array}$ & $\begin{array}{c}\left(10^{6} \text { cá }\right. \\
\text { thể }\end{array}$ & $\begin{array}{c}\text { Tỉ lệ } \\
(\%)\end{array}$ & tấn & $\begin{array}{c}\text { Tỉ lệ } \\
(\%)\end{array}$ & $\begin{array}{c}\left(10^{6} \text { cá }\right. \\
\text { thể })\end{array}$ & $\begin{array}{c}\text { Tỉ lệ } \\
(\%)\end{array}$ \\
\hline$<10$ & 45.754 & 13,0 & 944.541 & 50,9 & 28.219 & 15,9 & 274.952 & 32,4 \\
\hline $10-15$ & 280.897 & 79,9 & 871.099 & 46,9 & 147.638 & 83,2 & 571.989 & 67,3 \\
\hline$>15$ & 24.741 & 7,0 & 40.188 & 2,2 & 1.536 & 0,9 & 2.579 & 0,3 \\
\hline Tổng & 351.392 & 100,0 & 1.855 .828 & 100,0 & 177.394 & 100,0 & 849.520 & 100,0 \\
\hline
\end{tabular}

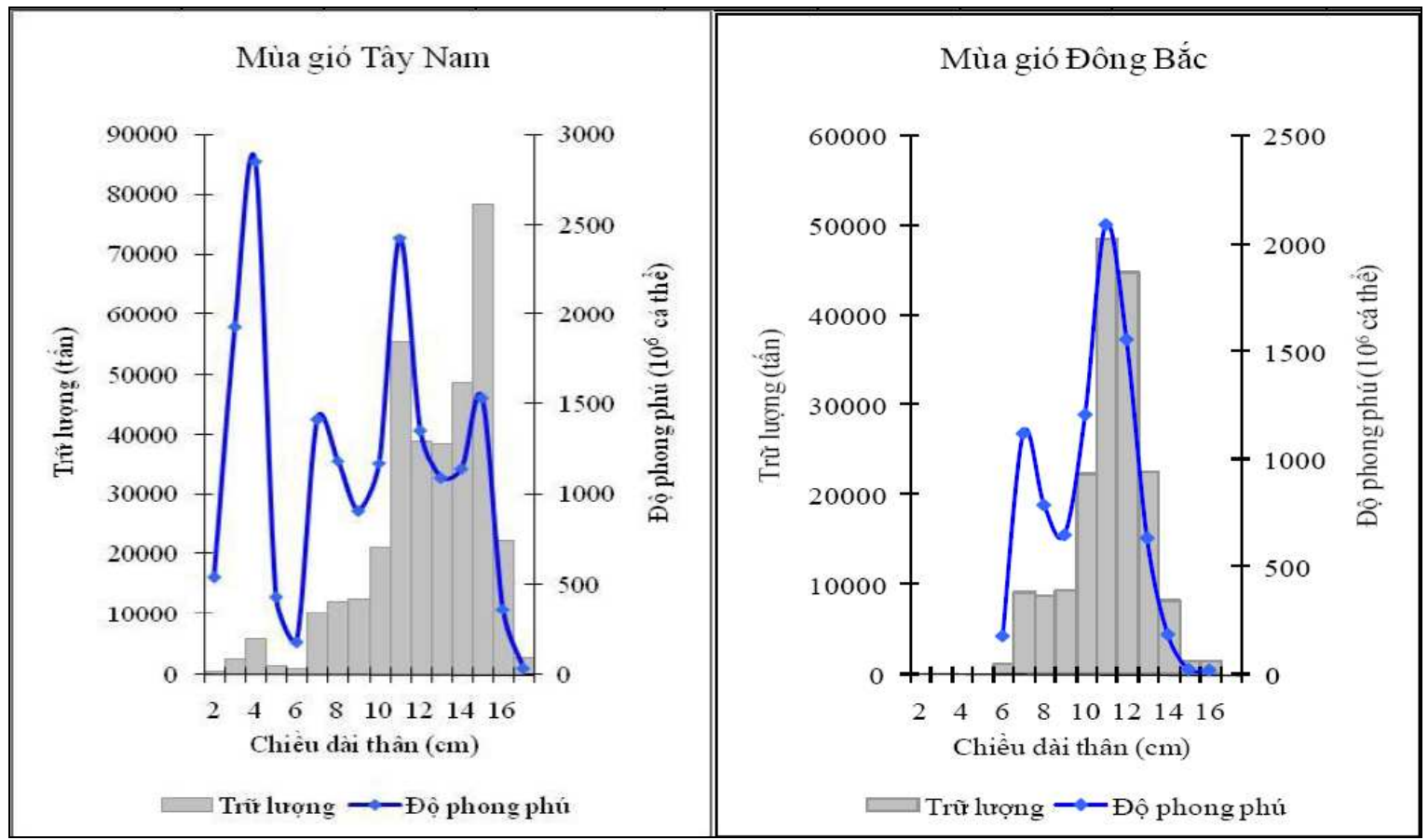

Hình 3: Trữ lượng (tấn) và độ phong phú (cá thể) nguồn lợi cá chỉ vàng (Selaroides leptolepis) theo nhóm chiều dài 


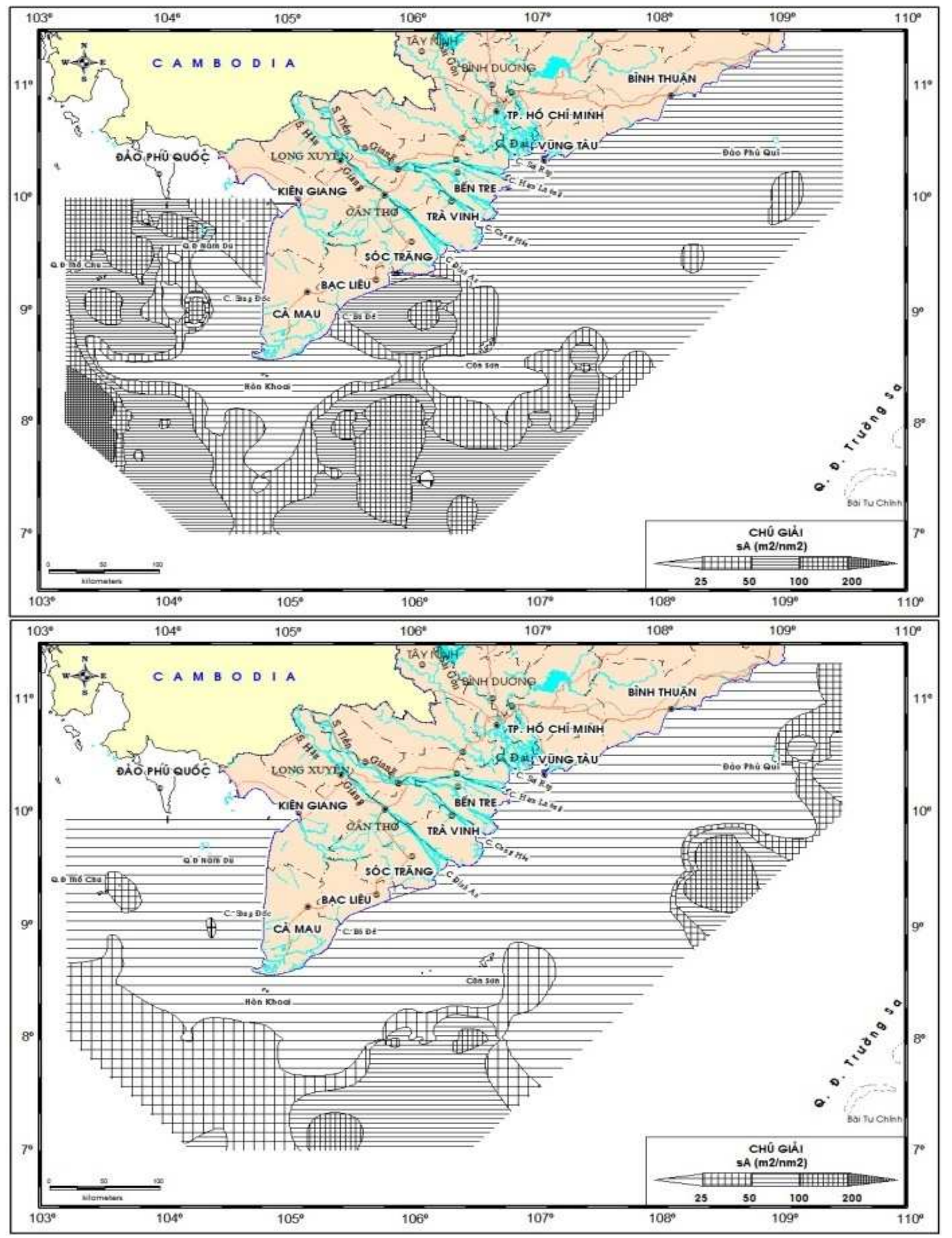

Hình 4: Phân bố của cá chỉ vàng ở mùa gió Tây Nam (trên) và ở mùa gió Đông Bắc (dưới) 


\section{Phân bố}

Phân bố không gian của cá chỉ vàng ở vùng biển phía Nam Việt Nam thể hiện sự phụ thuộc vào mùa gió rất rõ. Ở mùa gió Tây Nam, cá chỉ vàng phân bố gần bờ hơn. Khu vực phân bố với mật độ cao chủ yếu là vùng ven bờ Bạc Liêu và Kiên Giang và khu vực đảo Thổ Chu. Trong khi đó, ở mùa gió Đông Bắc, vùng biển ven bờ là khu vực có mật độ phân bố thấp. Phía Đông đảo Phú Quý và phía Nam đảo Côn Sơn là những khu vực mật độ phân bố của cá chỉ vàng cao hơn so với các khu vực khác (Hình 4).

Kết quả so sánh thống kê phân bố của các loài cá cá chỉ vàng ở mùa gió Tây Nam và mùa gió Đông Bắc cho thấy sự khác nhau trong phân bố của loài giữa hai mùa gió có ý nghĩa thống kê với độ tin cậy 95\% (Man-Whiney U test, $\mathrm{p}<0,001$ ).

Trong nghiên cứu này, 9 mặt cắt song song đã được thiết kế với tổng chiều dài tuyến đường dò là 2.565 hải lý, bao phủ hầu hết vùng biển nghiên cứu. Với khoảng cách giữa các điểm nút trích xuất thông tin về diện tích âm phản hồi trên tuyến đường dò là 5 hải lý, trữ lượng nguồn lợi cá bạc má và khu vực phân bố tập trung của từng loài trong vùng biển nghiên cứu đã được xác định đảm bảo độ chính xác cao nhất.

\section{KẾT LUẬN}

Trữ lượng nguồn lợi cá chỉ vàng ở vùng biển phía Nam Việt Nam ước tính khoảng 177-351 ngàn tấn. Cấu trúc quần thể cá chỉ vàng có sự khác biệt khá rõ giữa mùa gió Đông Bắc và mùa gió Tây Nam thể hiện ở tỉ lệ trữ lượng và độ phong phú của các nhóm chiều dài trong quần thể.

Ở mùa gió Tây Nam, trữ lượng và độ phong phú nguồn lợi cá chỉ vàng thuộc nhóm dưới $10 \mathrm{~cm}$ chiếm ưu thế so với ở mùa gió Đông Bắc, chứng tỏ lượng bổ sung của các loài cá này chủ yếu diễn ra vào mùa gió Tây Nam

Khu vực phân bố tập trung của cá chỉ vàng có sự khác biệt giữa mùa gió Tây Nam và mùa gió Đông Bắc. Trong mùa gió Đông Bắc, vùng biển giới hạn từ $9^{\circ} 00 \mathrm{~N}$ xuống phía Nam có mật độ phân bố cá chỉ vàng cao hơn so với vùng biển từ $9^{\circ} 00 \mathrm{~N}$ trở lên phía Bắc. Ở mùa gió Tây Nam khu vực phân bố tập trung nằm rải rác, trong đó các vùng biển phía Đông Nam đảo Phú Quý, ngoài khơi đảo Côn Sơn và khu vực phía Nam mũi Cà Mau là nơi có mật độ phân bố cao hơn. 


\section{TÀI LIỆU THAM KHẢO}

1. Vũ Việt Hà, Đặng Văn Thi \& Nguyễn Duy Thành, 2005. Tổng quan nguồn lợi và hệ sinh thái vùng biển miền Trung. Viện Nghiên cứu Hải sản, Hải Phòng.

2. Nguyễn Viết Nghĩa, 2007. Báo cáo tổng kết đề tài "Nghiên cứu trữ lượng và khả năng khai thác các loài cá nổi nhỏ chủ yếu là cá Nục, cá Trích, cá Bạc má ở biển Việt Nam". Viện Nghiên cứu Hải sản, Hải Phòng.

3. Đặng Văn Thi, Nguyễn Bá Thông \& Vũ Việt Hà, 2005. Tổng quan nguồn lợi và hệ sinh thái vùng biển vịnh Bắc bộ. Viện Nghiên cứu Hải sản, Hải Phòng: 68 trang.

4. Đặng Văn Thi, Nguyễn Bá Thông \& Vũ Việt Hà, 2005. Tổng quan nguồn lợi và hệ sinh thái vùng biển Đông Nam bộ. Viện Nghiên cứu Hải sản, Hải Phòng: 56 trang.

5. Toresen R., Gjøsæter H. \& de Barros P., 1998. The acoustic method as used in the abundance estimation of capelin (Mallotus villosus Müller) and herring (Clupea harengus Linné) in the Barents Sea. Fisheries Research 34(1): p. 27-37.

6. Aglen A., 1994. Sources of Error in Acoustic Estimation of Fish Abundance, in Fernö, A. and S. Olsen (eds.). Marine Fish Behaviour in Capture and Abundance Estimation, Fishing News Books, Oxford. p. 107-133

7. Foote K. G., 1987. Fish target strengths for use in echo integrator surveys. Journal of the Acoustical Society of America 82(3): p. 981-987.

8. Foote K. G., Knudsen K. P., Vestnes G., MacLennan D. N. \& Simmonds E. J., 1987. Calibration of acoustic instruments for fish density estimation: a practical guide. ICES Cooperation Research Report 144(-): p. 69 pp.

9. Froese, R. \& Pauly, D. Editors, 2009. FishBase. World Wide Web electronic publication. www.fishbase.org, version (07/2009)

10. Knudsen H. P. (1989). Bergen Echo Integrator: an introduction. ICES, Doc. C. M. 1989/B:9.

11. Paxton J. R., Hoese D. F., Allen G. R. \& Hanley J. E., 1989. Pisces. Petromyzontidae to Carangidae. Zoological Catalogue of Australia, Vol. 7. 1989: Australian Government Publishing Service, Canberra. 


\title{
STOCK BIOMASS AND DISTRIBUTION OF YELLOWSTRIP SCAD (SELAROIDES LEPTOLEPIS) IN THE SOUTHERN SEA OF VIETNAM BASED ON FISHERIES ACOUSTIC SURVEYS
}

\author{
VU VIET HA
}

\begin{abstract}
Summary: Fisheries acoustic data collected in 2005 were used to estimate stock biomass and spatial distribution of Yellowstrip scad the Southern Sea of Vietnam. Standing stock biomass of fish was estimated in the ranges from 177 - 351 thousand tons. Stock structure and distribution of Yellowstrip scad were differences seasonally. In the southwest monsoon season, population of Yellowstrip scad dominated by less than $10 \mathrm{~cm}$ sized fish while in the southwest monsoon fish was mostly over $10 \mathrm{~cm}$ in body length. It is suggested that recruitment of yellowstrip scad are in the southwest monsoon season. Results aldo indicated that the distribution of fish was effected by monsoon season pattern with high fish concentration from $9^{\circ} 00 N$ southwards in the Northeast monsoon and scaterred in the southernmost of Phuquy Island, off the Conson Island and southernmost of Camau cape during the Southwest monsoon season.
\end{abstract}

Key words: acoustics, Yellowstrip scad, biomass, abundance

Ngày nhận bài: 21 - 3 - 2011

Ngưòi nhận xét: PGS. TS. Nguyễn Hữu Phụng 